\title{
On the Feasibility and Desirability of Learner Autonomy from Iranian EFL Teachers' Perspectives
}

\author{
Goudarz Alibakhshi (Corresponding author) \\ English language \& Literature department, Faculty of Foreign Languages \& Persian Literature, Allameh Tabataba' University, Tehran, Iran \\ E-mail: alibakhshi@atu.ac.ir \\ Alireza Keikha \\ Department of Education, Zabol, Iran \\ Behzad Nezakatgoo \\ English language \& Literature department, Faculty of Foreign Languages \& Persian Literature, Allameh Tabataba' University, Tehran, Iran \\ E-mail: bnezakatgoo@atu.ac.ir
}

Received: 28-04- 2015

Published: 01-11- 2015
Accepted: 13-07- 2015

doi:10.7575/aiac.ijalel.v.4n.6p.141
Advance Access Published: August 2015

URL: http://dx.doi.org/10.7575/aiac.ijalel.v.4n.6p.141

\begin{abstract}
Learner autonomy has been a controversial issue among teachers in general and teachers of English as a foreign language (EFL) in particular. However, it seems that private institutes and state high school EFL teachers' beliefs about feasibility and desirability of learner autonomy (LA) have not been compared. This study aimed at investigating the feasibility and desirability of learner autonomy from English language teachers' perspectives. In doing so, the learner autonomy instrument consisting of feasibility and desirability sections was administered to 120 EFL teachers (sixty high school teachers and sixty language institute teachers). The participants were selected through convenience sampling. The data of the study were analyzed through descriptive and inferential statistics (one- sample t-test and Wilcoxon test). The results showed that both private institutes and state high schools EFL teachers have positive perceptions about learner autonomy. However, they do not have the same beliefs about feasibility and desirability of learner autonomy.
\end{abstract}

Keywords: Learner autonomy, feasibility, desirability, EFL teachers, Iranian EFL teachers

\section{Introduction}

Learner autonomy has a long history in English Language Teaching (ELT) but only has it been studied in the field of ELT in the last decade (Smith, 2008). Learners' beliefs have been of great interest in ELT in the last four decades. There exists an extensive literature on this issue. It has been discussed in relation to various concepts such as its underlying dimensions (Cotterall, 1995), language learning strategies (Wenden, 1991, 1998), language proficiency (Johnson, 2006) and culture (Horwitz, 1998).

Teachers' beliefs, to a lesser extent than learners' beliefs, have been researched in relation to their effects on teaching behavior (Borg, 1998). The issue of teachers' and students' beliefs about learner autonomy has not attracted much study. There are some studies concerning learner beliefs' about learner autonomy, teachers' belief about leaner autonomy (Al Shaqsi, 2009; Camilleri, 1999; Chan, 2001, 2003), teacher students' belief about learner autonomy (Balçıkanlı, 2010) and to a lesser extent beliefs of EFL learners with different levels of proficiency about learner autonomy (Kuchak \& Smith, 2011). Moreover, almost all studies were carried out through quantitative research designs. Thus, there seems a need for a qualitative study on intermediate and advanced EFL learners ' beliefs about leaner autonomy.

The main objective of the present study is to explore Iranian EFL teachers' perceptions of learner autonomy. More specifically, it aims at investigating Iranian English language teachers at language institutes regarding desirability and feasibility of learner autonomy. It also aims at investigating whether there is a significant difference between the perceptions of English language teachers at language institutes concerning feasibility and desirability of learner autonomy. In line with the objectives of the study, the following research questions were raised:

1. What are the beliefs of English language teachers of Iranian language institutes (LI) about feasibility of learner autonomy in foreign language learning?

2. What are the beliefs of English language teachers of Iranian language institutes (LI) about desirability of learner autonomy in foreign language learning?

3. Is there any significant difference between the teachers' perceptions about the feasibility and desirability of learner autonomy? 


\section{Review of literature}

\subsection{Learner Autonomy}

Benson (2011) provides a comprehensive analysis of key issues in learner autonomy, while there have also been a number of edited collections dedicated to the topic (Pemberton, Toogood, \& Barfield, 2009; Vieira, 2009; Lamb \& Reinders, 2008; Little, Ridley, \& Ushioda, 2003; Palfreyman \& Smith, 2003).

In the narrower definition, it refers to the use of self study materials (Benson, 2007). In the broader sense, it refers to the situation in which learners study entirely or largely on their own without the help of any instructor (Benson, 2007). Distance learning has enjoyed a growth in the recent years and has begun to merge with CALL through issues such as "online learning" (White, 2003). Tandem learning refers to the process in which "two people who are learning each others' language work together to help one another" (Lewis, 2005, p. 106). Study abroad refers to that kind of language learning in which there are language learning programs which allot a certain period of their course to happen in the target language community (Benson, 2007).

There are various approaches to promote learner autonomy. Benson (2001) proposes six approaches including "Resource-based", "Technology-based", "Teacher-based", "Classroom-based", "Curriculum-based", and "Learnerbased approaches".

Resource-based approach focuses on the interplay between learner and learning material (Benson, 2001). This approach gives the learners the opportunity of controlling the process of learning, selecting materials, and self evaluating (Sheerin, 1997). Thus, learners can take more responsibility for their own learning. Self-access, self-instruction, and distance learning are grouped within this approach.

Technology-based approach includes computer assisted language learning (CALL). This approach is mainly concerned with the usage of technology in language instruction (Sabanci, 2007). Learners benefit freedom to control and direct their learning which affirms the efficiency of this approach in the development of autonomy (Benson, 2001).

Teacher-based approach is concerned with teachers' professional development in terms of gaining knowledge on how to develop and encourage learner autonomy in their learners (Gökgöz, 2008). This knowledge is important to the development of learner autonomy since teachers are mostly the initiators of autonomy (Sabanci, 2007). It is assumed that teacher autonomy is a prerequisite for the development of learner autonomy.

Classroom-based approach emphasizes the changes that happen in the relationship between teacher and learner in the classroom (Benson, 2001). Since this approach is concerned with providing learners with opportunities which enhance and foster autonomy, it leads to learners being able to decide over learning activities, and the evaluation of their learning outcomes (Benson, 2001).

Curriculum-based approach enhances the learners' control over management, planning, and evaluation of learning to the curriculum as a whole (Benson, 2001). When learners are monitoring the curriculum, they have to consider their preferences related to concepts including "learning approaches, attitudes toward learning, learning styles, strategies used in learning, learning activities, patterns of interaction, degree of learner control over their own learning, what constitutes effective teaching and the nature of effective learning" (Brown, 1995, p. 187). This approach is capable of fostering autonomy since learners feel that their opinions and decisions are taken into account (Gökgöz, 2008). Furthermore, they will be motivated to participate in the learning of the curriculum which they have partially created (Gökgöz, 2008).

Learner-based approach emphasizes the production of psychological and behavioral changes in the learners (Benson, 2001). This approach is mainly concerned with learner development and learner training in strategies, skills, and techniques. This approach is effective in promoting learner autonomy since it gives learners the opportunity to take more control over their learning (Dickinson, 1995).

\subsection{Teachers' Beliefs}

The second strand of our theoretical framework draws on research in the field of language teacher cognition, which is defined as the study of what teachers think, know and believe (Borg, 2006). In her review of trends in language teacher education, Johnson (2006) described teacher cognition as the area of research which has made the most significant contribution in the last 40 years to our understandings of teachers and teaching. It has been a very productive field of research in language teaching since the mid-1990s and this work has established a number of insights about the nature of teachers' beliefs and their role in language teaching and teacher learning which are now widely accepted (for a summary of these insights, see Phipps \& Borg, 2009). For the purposes of this study, two particular points are important.

First, teachers' beliefs can powerfully shape both what teachers do and, consequently, the learning opportunities learners receive. Therefore the extent to and manner in which learner autonomy is promoted in language learning classrooms will be influenced by teachers' beliefs about what autonomy actually is, its desirability and feasibility. Second, teacher education is more likely to have an impact on teachers' practices when it is based on an understanding of the beliefs teachers hold (Borg, 2011). Understanding teachers' beliefs about autonomy is thus an essential element in the design of professional development activities aimed at promoting learner autonomy.

While the major focus of learner autonomy is on learners, the role of the teacher is not ignored (Camilleri, 1999). The importance of the role the teacher plays in the autonomous learning environment is captured by Barfield et al. (2001) who hold that learner autonomy is dependent on teachers creating a learning context in which autonomy is accepted. Camilleri (1999) lists some characteristics that a teacher in an autonomous learning environment needs to develop including self-awareness, understanding pedagogy, skill in classroom management. In this context, the teacher transfers 
role from an imparter of information to a manager, a resource person, and a counselor (Camilleri, 1999). The teacher as manager manages the learning activities. He/she must make clear the most proper paths that students can take in order to achieve their goals. In other words, the teacher should plan, short term and long term, for both individuals and groups. The teacher as a resource person prepares the learning conditions properly by raising learners' awareness of a wide range of learning strategies. An example includes helping learners becoming aware of learning styles. The teacher as counsellor has the ability to "accompany individual learning processes" (p. 38) and to react in an efficient manner usually before students feel a need to learning problems.

Little (1995) argues that learners find it difficult to take responsibility for their own learning in the new autonomy oriented learning situation. Therefore, teachers are required to encourage learner autonomy in the classrooms. Nunan (1997) talks about levels for encouraging learner autonomy including "awareness", "involvement", "intervention", "creation", and "transcendence". In the awareness level, learners become aware of the course goals and materials. In the involvement level, learners select their own goals from among alternatives and in the intervention level modify and adapt the course goal and content. In the creation level, learners create their own goals and in the final level, transcendence, learners apply the course content to the real world context. Cotterall (2000) in his article about promoting learner autonomy through curriculum development names five principles which contribute to the transfer of responsibility for decision making about learning issues form teacher to learners. These principles include a) the course reflects learners' goals in its language, tasks, and strategies, b) course tasks are explicitly linked to a simplified model of the language learning process, c) course tasks either replicate real-world communicative tasks or provide rehearsal for such tasks, d) The course incorporates discussion and practice with strategies known to facilitate task performance, and e) The course promotes reflection on learning.

Teachers' beliefs are a system consisting of core and peripheral beliefs (Green, 1971, and Pajares, 1992, cited in Phipps \& Borg, 2009, p. 381). Core beliefs enjoy stability and are more influential on behaviour than peripheral beliefs (Phipps \& Borg, 2009). Like learners' beliefs which have the potential to influence their achievement, teachers' beliefs play a major role in the development of their practice (Richards, Gallo, \& Renandya, 2001). Studying teachers' beliefs helps in understanding how they conceptualize and approach their work (Richards, Gallo, \& Renandya, 2001).

Phipps and Borg (2009), in their review of literature on teacher' beliefs both in general education and specifically in relation to language teaching, hold that teachers' beliefs about teaching and learning, a) may be negatively or positively influenced by teachers' previous experiences as learners and are well formed by the time they enter university (Holt Reynolds, 1992; Lortie, 1975), b) are used by teachers for interpretation of new information and experience (Pajares, 1992), c) may be more powerful in effecting teachers' action in the classroom than their teacher training courses/ teacher education (Kagan, 1992; Richardson, 1996), d) can have enduring long term influence on teachers' professional practice (Crawley \& Salyer, 1995), e) are not always reflected in teachers' practice (Dobson \& Dobson, 1983; Pearson, 1985; Tabachnick \& Zeichner, 1986), f) can influence and be influenced by practices (Richardson, 1996), g) greatly influence teachers' pedagogical decisions (Johnson, 1994), h) immensely effects the content, the extent, and the method of learning of that specific teacher during teacher education programs (Freeman \& Richards, 1996), and i) can resist against change (Almarza, 1996; Pickering, 2005).

Balçıkanlı (2010) investigated student teachers' beliefs about learner autonomy in the Turkish educational context. The study aimed to find out student teachers' beliefs about learner autonomy, the areas of learner autonomy they perceived as important, and the constraints in the way of development of autonomy. The results of the questionnaire showed that the participants considered autonomy essential for nearly all areas particularly methodology and classroom management. They thought positively about the involvement of learners in selecting materials and deciding on methodology consisting of individual/pair group work, use of materials, type of class activities and type of homework activities, classroom management issues such as arranging the position of desks, seating of students, and discipline matters, assessing themselves and setting short and long term objectives.

Al Shaqsi (2009) examined beliefs held by teachers of English in Oman about the extent to which their learners are autonomous. The study was conducted in the Dakhiliya Region of Oman with 100 teachers of English (55 were male and 45 female) who were teaching Grades 10-12 (the last three years of secondary school), where learners were aged 15-17. Data were collected through a five point Likert scale questionnaire. The questionnaire had three parts: personal information, characteristics of autonomous learners, and teachers' beliefs about how autonomous their own learners were. The responses ranged from strongly agree $=5$ to strongly disagree $=1$. Part 2 of the questionnaire had a list of nine characters of autonomous learners. The findings showed that teachers assessed heir students positively in all behaviors. The three highest scaled behaviors were learners' ability to ask the teacher to explain in cases of ambiguity, to express their opinions about topics talked about in the classroom, and to use their dictionary properly. The female participants voted for the "Give their point of views on topics in the classroom" while the male counterparts gave the highest priority to "Ask the teacher to explain when something is not clear". Female teachers thought their learners possessing a more autonomous character than did the male ones toward their learners.

Nicolaides (2008) investigated language learners' beliefs about the roles they believed they had in the development of their language learning including autonomy. In the same vein, Benson (2008) analyzed the differences between teachers' and learners' perspective on learner autonomy and how these differences may be related to the technical, psychological, and political versions of autonomy. The researcher claimed that since the concept of autonomy in learning derives its meaning from the concept of personal autonomy, it mainly involves the kind of learning which best helps people to lead autonomous lives. In other words, the issue of autonomy can be fundamentally interpreted as the outcome of the relationship between broader views of autonomy in life and teaching and learning issues. In spite of this 
fact, the theory of autonomy in language learning is largely formulated and extended by teachers' perspective in the classroom, resulting in a focus on the "development of the internal capacity for autonomy at the expense of external freedom in the learning process" (p. 30).

\section{Method}

\subsection{Sampling}

The participants of the present study were 120 EFL teachers who were elected from English language teachers at English language institutes in Sistan and Baluchestan, Khorasan Razavi, and Kerman provinces. The criteria for selection of these participants were: five years experience in teaching at language institutes, English language teaching certificate either from the universities or English language teaching training centers. All participants were selected through convenience sampling. Before administering the questionnaire, the participants were informed of the purpose of the study and the confidentiality of the results and were also presented with a general description of the concept of autonomy.

\subsection{Instruments}

3.2.1 English Language Teachers' Beliefs about Learner Autonomy

In order to elicit teachers' beliefs about learner autonomy, the questionnaire of 'English Language Teachers' Beliefs about Learner Autonomy" developed by British Council was used. The questionnaire has two parts. The first part deals with participants' perceptions of learner autonomy. The first part consists of 37 statements on a five point Likert scale, including " $1=$ strongly disagree " $2=$ disagree", " $3=$ unsure", " $4=$ agree", and " $5=$ strongly agree". The second part consists of investigating teachers' view on the feasibility and desirability of learners involvement in decisions about the objectives of a course, the materials used, the kinds of tasks and activities they do, the topics discussed how learning is assessed, the teaching methods used, and classroom management. It also consists of statements dealing with Learners' ability to: identify their own needs, identify their own strengths, identify their own weaknesses, monitor their progress, evaluate their own learning, learn co-operatively, and learn independently. In this study, the second part of the study which delineates the participants' perceptions about desirability of feasibility of LA was administered to the participants.

The rationale for using questionnaire for this study was that according to Burton and Bartlett (2005) questionnaires are appropriate and practical instruments of data collection from large groups of participants. The reliability of the instrument was calculated through Cronbach alpha. The estimated alpha was .81 which indicates high reliability (Sabanci, 2007).

\subsection{Data Analysis}

The closed questionnaire data were analyzed statistically using SPSS 18. Descriptive statistics (i.e. frequency counts and percentages) were calculated for all questions. Inferential statistics such as one sample t-test was calculated to see whether there was a difference between sample and population. In addition, independent sample t-tests were calculated to compare the mean scores of teachers at language institutes and teachers at universities on learner autonomy.

\section{Results}

4.1 Research Question 1

At first descriptive statistics for the first section of the questionnaire is presented in Table 1

Table.1. Descriptive statistics and one sample t-test for teachers' perceptions about desirability of LA

\begin{tabular}{lllll}
\hline & Mean & t & df & Sig. (2-tailed) \\
\hline 1. Objectives of the course & 2.81 & 19.8 & 26 & 0.001 \\
2. The materials used & 2.9 & 19.4 & 26 & 0.001 \\
3. The kinds of activities they do & 3.07 & 19.2 & 26 & 0.001 \\
4. The topics discussed & 3.14 & 30.6 & 26 & 0.001 \\
5.How learning is assessed & 2.62 & 16.9 & 26 & 0.001 \\
6. The teaching methods used & 3.07 & 16.2 & 26 & 0.001 \\
7. Classroom management & 2.8 & 15.4 & 26 & 0.001 \\
8. Learners' ability to identify their needs & 2.6 & 22.3 & 26 & 0.001 \\
9. Learners' ability to identify their strengths & 3 & 22.9 & 26 & 0.001 \\
10. Learners' ability to identify their weaknesses & 2.7 & 16.1 & 26 & 0.001 \\
11. Learners' ability to monitor their progress & 2.7 & 20.6 & 26 & 0.001 \\
12. Learners' ability to evaluate their own learning & 3.07 & 23.69 & 26 & 0.001 \\
13. Learners' ability to learn cooperatively & 2.5 & 12.6 & 26 & 0.001 \\
14. Learners' ability to learn independently & 3.07 & 17.5 & 26 & 0.001 \\
\hline
\end{tabular}

The results in the above table show that the mean of LI teachers' perceptions about the above items which are indicators of learners' autonomy exceed 2.5. That is language teachers were positive about the desirability of the learners in a range of language course decisions. The results also show that $\mathrm{p}$ value for all items is 00.001 which is less than the critical $p$ value of 0.05 favoring the sample. Therefore, it could be argued that EFL teachers of LIs have a positive 
perception about the feasibility of learners' autonomy in all variables. The results also indicate that that they are more positive about the learners' autonomy in the topics discussed in the classroom (Mean=3.14), followed by the kinds of activities they do, teaching methods, their ability to evaluate their own learning, and their ability to learn independently $($ mean $=3)$.

The results also show that learners' autonomy in materials (2.9) which are used in ranked the next followed by classroom management and objectives of the course. However LI teachers were less positive about the learners' autonomy in identifying their own needs and leaning cooperatively. The order to see whether, the distribution of the desirability of learners' autonomy is the same or not, Friedman test was run. The results are shown in table 4.2.

Table 2. Teachers' perceptions about feasibility of learners' autonomy

\begin{tabular}{lllll}
\hline & Mean & t & df & Sig. (2-tailed) \\
\hline 1. Objectives of the course & 2.8 & 13.1 & 29 & 0.001 \\
2. The materials used & 2.8 & 16.8 & 29 & 0.001 \\
3. The kinds of activities they do & 2.8 & 16.3 & 29 & 0.001 \\
4. The topics discussed & 2.8 & 18.1 & 29 & 0.001 \\
5.How learning is assessed & 2.7 & 17.5 & 29 & 0.001 \\
6. The teaching methods used & 2.5 & 15.6 & 29 & 0.001 \\
7. Classroom management & 2.6 & 14.7 & 29 & 0.001 \\
8. Learners' ability to identify their needs & 2.5 & 14.9 & 29 & 0.001 \\
9. Learners' ability to identify their strengths & 2.6 & 19.8 & 29 & 0.001 \\
10. Learners' ability to identify their weaknesses & 2.6 & 24.1 & 29 & 0.001 \\
11. Learners' ability to monitor their progress & 2.6 & 19.8 & 29 & 0.001 \\
12. Learners' ability to evaluate their own learning & 2.6 & 20.3 & 29 & 0.001 \\
13. Learners' ability to learn cooperatively & 2.5 & 17.3 & 29 & 0.001 \\
14. Learners' ability to learn independently & 2.7 & 15.7 & 29 & 0.001 \\
\hline
\end{tabular}

The results in the above table show that student involvement in decision making was seen to be the most feasible in objectives of the course, the materials used, kinds of activities they do, the topics discussed (mean=8) the results also show that student involvement in decision making was seen to be most feasible in relation to how learning is assessed and their ability to learn independently, least feasible decision making about teaching methods used and learners abilities to learn cooperatively.

The results of one sample t-test in (the sig column) show that that $\mathrm{p}$ value for all items is 00.001 which is less than the critical $p$ value of 0.05 favoring the sample. Therefore, it could be argued that English language teachers of language institutes have a positive perception about the feasibility of learners' autonomy in all variables. That is, it is possible and feasible for language learners attending language institutes to be autonomous in the above mentioned variables which indicate learners' autonomy.

Table 3: Wilcoxon test for comparing institute teachers' perceptions about feasibility and desirability of learners' autonomy

\begin{tabular}{llll|l}
\hline & & \multicolumn{3}{l}{ Sig. (2-tailed) } \\
\cline { 4 - 5 } & F M & DM & Z & Sig \\
\hline 1. Objectives of the course & 2.8 & 2.81 & -1.9 & 0.05 \\
2. The materials used & 2.8 & 2.9 & -.3 & 0.7 \\
3. The kinds of activities they do & 2.8 & 3 & -1.1 & 0.2 \\
4. The topics discussed & 2.8 & 3.1 & -.2 & 0.04 \\
5.How learning is assessed & 2.7 & 2.6 & -.2 & 0.02 \\
6. The teaching methods used & 2.5 & 3 & -6 & 0.5 \\
7. Classroom management & 2.6 & 2.8 & -6 & 0.5 \\
8. Learners' ability to identify their needs & 2.5 & 2.6 &.-9 & 0.3 \\
9. Learners' ability to identify their strengths & 2.6 & 3 & -1.7 & 0.07 \\
10. Learners' ability to identify their weaknesses & 2.6 & 2.7 & -.5 & .67 \\
11. Learners' ability to monitor their progress & 2.6 & 2.7 & -.58 & .55 \\
12. Learners' ability to evaluate their own learning & 2.6 & 3.07 & -1.9 & 0.05 \\
13. Learners' ability to learn cooperatively & 2.5 & 2.5 & -6 & 0.5 \\
14. Learners' ability to learn independently & 2.7 & 3.07 &.-9 & 0.3 \\
\hline
\end{tabular}


The results in the above table show that on five items (objectives of the course, kinds of activities they do, the topics discussed, assessment, and ability to evaluate learning) there are statistically significant differences between feasibility and desirability of learners' autonomy ( $\mathrm{p}$ value is less than 0.05 , as shown by the Wilcoxon signed ranks test 1 ).

\section{Discussion}

The first question of the present study addressed the perceptions of Language Institutes (LI) teachers about desirability and feasibility, of involving learners in a range of language course decisions and desirability and feasibility of developing a range of abilities that are commonly seen as indicators of learner autonomy. The results in Tables 1,2 , and 3 showed that EFL teachers hold positive perceptions about the desirability and feasibility of involving the language learners in a range of language course decisions. This findings are consistent with the findings of several studies mentioned in the review of literature ( e.g., Phipps \& Borg, 2009; Richards, Gallo, \& Renandya, 2001; Pajares, 1992; Kagan, 1992; Richardson, 1996; Crawley \& Salyer; , 1995; Dobson \& Dobson, 1983; Pearson, 1985; Tabachnick \& Zeichner, 1986; Freeman \& Richards, 1996; Almarza, 1996; Pickering, 2005; Sabanci, 2007; Édes , 2009).

The results also showed that, according to EFL teachers, there are statistically significant differences between feasibility and desirability of learners' autonomy in terms of objectives of the course, kinds of activities they do, the topics discussed, assessment, and ability to evaluate learning. That is, in these cases teachers were more positive about the feasibility of student involvement than they were about their desirability. It could be justified that teachers think that is possible to have learners involved in making decisions about the objectives of the course, teaching and learning activities, assessment and evaluation methods although they not heartedly like it. One reason for their reluctance for involving learners in the above mentioned activities as Nunan (1997) believes, is that they afraid to lose their autonomy.

Another reason for such a reluctance, as Alibakhshi (2014) argues, is the challenges which teachers face while attempting to promote learner autonomy in making decisions about components of curriculum. He further argues that the challenges are related to learners, the institution, and teachers. Although the teachers felt strongly that institutional factors (e.g. the curriculum) did hinder the extent to which they could promote learner autonomy, most of the limiting factors they identified pointed to what they saw as problems with learners' attitudes, abilities, knowledge and motivation.

The feasibility of the learner autonomy in making decisions about components of curriculum is due to, as Benson (2007) believes, the learners' access to online and offline materials.

\section{Conclusion}

This study investigated EFL teachers' perceptions about learner autonomy. Based on the findings of the study, it could be concluded that teachers should try to promote learner autonomy and try to, through cooperation with different agents such as administrators and policy makers to increase the rate of learners' learner autonomy. Moreover, it should be attempted to provide the learners with the facilities to help them to become autonomous. It is also necessary to filter the psychological barriers and hindrance which make the learner autonomy possible.

As this study was carried out in a specific context and the sample size was not representative of the EFL population, the other researchers are recommended to replicate the study and collect qualitative and quantitative data so that they can deeply delve into the teachers perceptions about learner autonomy. As the other variables such as teachers' gender, degree, and experience might influence the teachers' perceptions about LA, the other researchers are recommended to replicate the study with regard to the teachers' gender, degree, and experience.

\section{References}

Alibakhshi, G. (2014). Challenges in promoting EFL learners' autonomy: Iranian EFL teachers' perspectives. ILT Journal. In press.

Al-Shaqsi, T. S. (2009). Teachers' beliefs about learner autonomy. In S. Borg (Ed.) (2011), Researching English language teaching and teacher development in Oman (pp. 157-165). Muscat: Ministry of Education, Oman.

Allwright, D. (2003) Exploratory practice: rethinking practitioner research in language teaching. Language Teaching Research, 7(2), 113-141.

Balçıkanlı, C. (2010). Learner autonomy in language learning: Student teachers' beliefs. Australian Journal of Teacher Education, 35(1), 90-103.

Benson, P. (2001). Teaching and researching autonomy in language learning. Harlow: Longman.

Barfield, A., \& Brown, S. (Eds.). (2007). Reconstructing autonomy in language education: Inquiry and innovation. Basingstoke: Palgrave Macmillan.

Benson, P. (2006). Autonomy in language teaching and learning. Language Teaching, 40(1), 21-40.

Benson, P. (2009). Making sense of autonomy in language learning. In R. Pemberton, S. Toogood \& A. Barfield (Eds.), Maintaining control: Autonomy and language learning (pp. 13-26). Hong Kong: Hong Kong University Press

Benson, P. (2007a). Teachers' and learners' perspectives on autonomy. In T. E. Lamb \& H. Reinders (Eds.), Learner and teacher autonomy: Concepts, realities and responses. Amsterdam: John Benjamins.

Benson, P. (2011). Teaching and researching autonomy in language learning (2nd ed.). Harlow: Longman. 
Benson, P. (Ed.). (2007b). Learner autonomy: Teacher and learner perspectives. Dublin: Authentik.

Borg, S. (2011). The impact of in-service teacher education on language teachers' beliefs. System, 39(3), $370-380$.

Borg, S. (2006). Teacher cognition and language education: Research and practice. London: Continuum.

Camilleri, G. (1999). Learner autonomy: The teachers' views. Retrieved 20 January 2012, from http://archive.ecml.at/documents/pubCamilleriG_E.pdf

Camilleri Grima, A. (2007). Pedagogy for autonomy, teachers' attitudes and institutional change: A case study. In M. Jimenez Raya \& L. Sercu (Eds.), Challenges in teacher development: Learner autonomy and intercultural competence. (pp. 81-102). Frankurt: Peter Lang.

Chan, V. (2001). Readiness for learner autonomy: what do our learners tell us? Teaching In Higher Education, 6(4), 505-518.

Chan, V. (2003). Autonomous Language Learning: the teachersee perspectives. Teaching In Higher Education, 8(1), 3354.

Cotterall, S. (1995). Developing a course strategy for learner autonomy. ELT Journal, 49(3), 219-227.

Creswell, J. W. (2006). Qualitative inquiry and research design: Choosing among five approaches. Thousand Oaks, CA: Sage Publications, Inc.

Dam, L. (1995). From theory to classroom practice. Dublin: Authentik.

Dickinson, L. (1995) Autonomy and motivation: a literature review. System, 23(2), 165-174.

Holec, H. (2008). Foreword. In T. E. Lamb \& H. Reinders (Eds.), Learner and teacher autonomy: Concepts, realities, and responses (pp. 3-4). Amsterdam: John Benjamins.

Horwitz, E. (1988). The beliefs about language learning of beginning university foreign

language students. The Modern Language Journal, 72(3), 283-294.

Johnson, K. E. (2006). The sociocultural turn and its challenges for second language teacher education. TESOL Quarterly, 40(1), 235-257.

Kuchah, K., \& Smith, R. (2011). Pedagogy of autonomy for difficult circumstances: From practice to principles. Innovation in Language Learning and Teaching, 5(2), 119-140.

Lamb, T. E., \& Reinders, H. (Eds.). (2008). Learner and teacher autonomy: Concepts, realities, and responses. Amsterdam: John Benjamins.

Little, D., Ridley, J., \& Ushioda, E. (Eds.). (2003). Learner autonomy in the foreign language classroom:Teacher, learner, curriculum and assessment. Dublin: Authentik.

Palfreyman, D. (2003). Introduction: Culture and learner autonomy. In D. Palfreyman \& R. C. Smith (Eds.), Learner autonomy across cultures: Language education perspectives (pp. 1-19). Basingstoke: Palgrave Macmillan.

Pemberton, R., Toogood, S., \& Barfield, A. (Eds.). (2009). Maintaining control: Autonomy and language learning. Hong Kong: Hong Kong University Press.

Smith, R. C. (2008). Learner autonomy (Key concepts in ELT). ELT Journal, 62(4),

395-397.

Vieira, F. (Ed.). (2009). Struggling for autonomy in language education. Frankfurt: Peter Lang.

Wenden, A. (1991). Learner strategies for learner autonomy: Planning and implementing learner training for language learners. UK: Prentice Hall International

Wenden, A. (1998). Learner Strategies for Learner Autonomy. Great Britain: Prentice Hall. 